\title{
On Designing Application of Finding Nearby Islamic Boarding Schools in West Java using Haversine Formula and Euclidean Distance Algorithms
}

\author{
Diena Rauda Ramdania ${ }^{1}$, Rian Andrian², Mohamad Irfan ${ }^{3}$, Rudi Zaenal Abidin ${ }^{4}$, \\ Faiz M Kaffah ${ }^{5}$ \\ \{diena.rauda@uinsgd.ac.id ${ }^{1}$, rian.adrian@if.uinsgd.ac.id ${ }^{2}$, irfan.bahaf@uinsgd.ac.id ${ }^{3}$ \} \\ Department of Informatics Engineering, UIN Sunan Gunung Djati Bandung ${ }^{1-5}$
}

\begin{abstract}
Islamic Boarding School is one of the alternative schools that are of interest to Indonesians. Finding the most appropriate boarding school is one of the initial strategies in determining schools. There are 25,938 pesantren in Indonesia, 8,264 of them are in West Java. The search for Islamic boarding schools is important considering the large number of them. This paper aims to tell the design of the search application for the nearest boarding school using Haversine Formula and Euclidean Distance algorithm. Applications that will be made compare the two methods so that they get the best results by using Longitude and Latitude calculations. The results showed that the application of the Haversine formula algorithm and the Euclidean distance on the nearest location search application was successfully built and could be used to find Islamic boarding schools in West Java. Haversine Formula and Euclidean Distance algorithms are able to provide distance accuracy to the location. But the Euclidean distance algorithm is more accurate than the haversine formula with a difference of $0.07 \mathrm{KM}$.
\end{abstract}

Keywords: Havesine Formula, Euclidean Distance Algorithm, Islamic Boarding School, location, Geographic information system.

\section{Introduction}

Indonesia is considered as a home for Muslims because it ranks first as the country with the highest number of Muslims in the world. About 202.9 billion Indonesians, or $87.2 \%$ of the population, embrace Islam [1]. This triggered the growth of Islamic boarding schools from year to year as the choice of Muslims to send their children to school [2]. Based on data from the Indonesian Ministry of Religion Headquarters, currently, there are 25,938 Islamic boarding schools spread in Indonesia [3]. Of the total existing pesantren, the province of West Java has the highest number of pesantren, $82.2 \%$ or as many as 8264 pesantren. With a provincial area of $35,378 \mathrm{~km}^{2}$, the location of Islamic boarding schools in West Java is spread throughout the region.

One of the things that are considered by parents in choosing a child's school is in terms of distance [4]. Sometimes parents or prospective students need to know which pesantren is ideally located with the criteria they have while knowing the profile of the pesantren. Knowledge about distance is also needed by employees of the Ministry of Religion when conducting surveys. Given the amount is not small, it takes an application that can facilitate the search for the location 
of Islamic boarding schools. For this reason, we created an application that can search for the location of the closest pesantren from the user's home location.
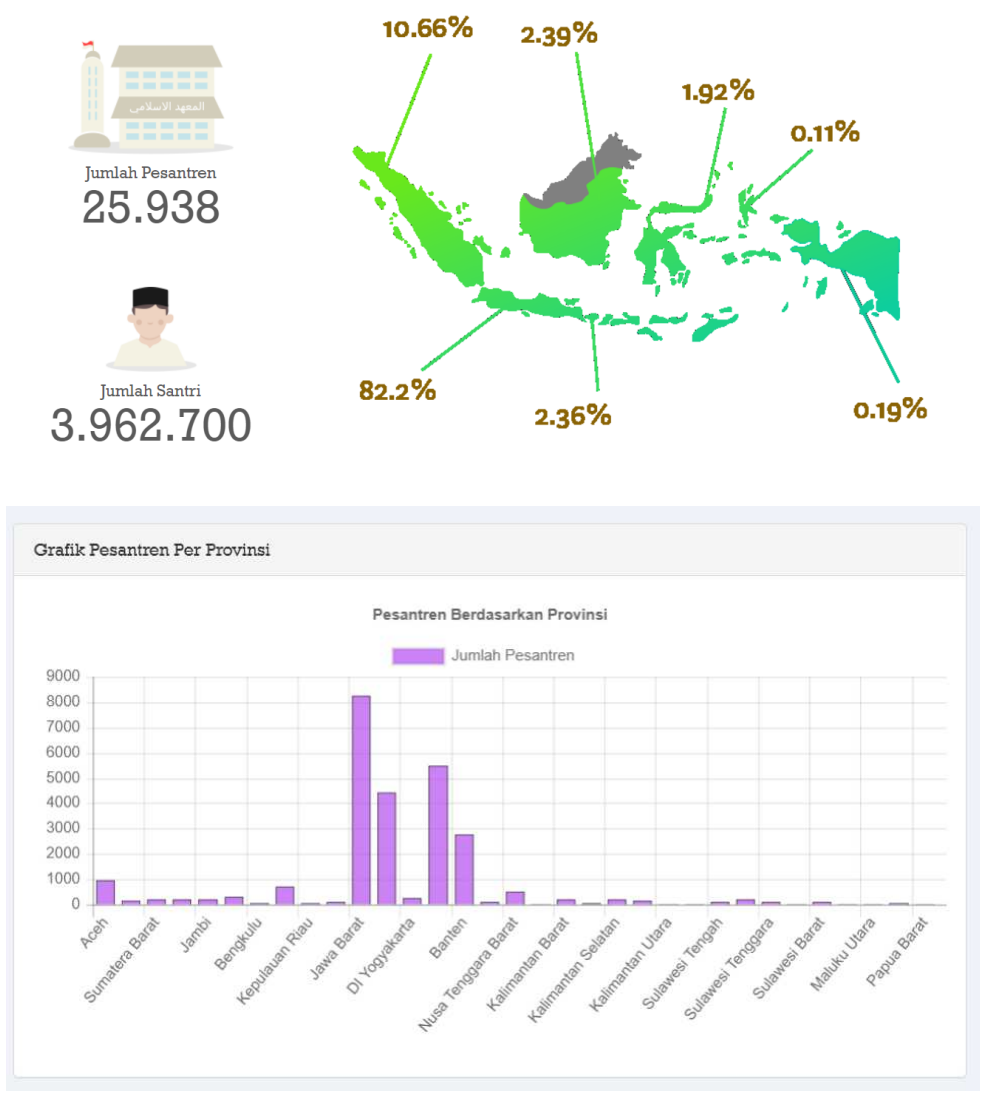

Figure 1. Islamic School Spread Statistics in Indonesia

The method used in this application is the Haversine Formula and Euclidian Distance Algorithm. The Haversine method has been used in research aimed at finding the nearest location, for example for the search for attractions [5], tourism locations [6], college locations [7], and searching for hospitals and health centers [8]. Based on previous research, this method is able to produce real distance calculations through sky and latitude calculations from several locations. The Euclidian Distance algorithm can also be used for location search. Like looking for attractions, culinary objects, and accommodations that can be used by users [9]. In this paper, we will present a system that applies the Haversine Formula and Euclidian Distance algorithms to search for the location of the nearest boarding school. Next, we will explain the performance of the two algorithms to find out which algorithm is better. 


\section{Haversine Formula}

The haversine formula is an important equation in the navigation system, later Haversine this formula will produce the shortest distance between two points, for example on a ball taken from longitude and latitude. This method calculates the distance between coordinate and other coordinates in a straight line and ignores the hills or valleys on the surface. The input of this method is in the form of latitude and longitude (coordinates) the location to be calculated and the output is in the form of distance values between the two locations. The coordinates used can vary depending on the application [5].

Navigation usually uses coordinates in longitude and latitude, while air navigation can also include heights. Waypoint is usually used for navigation systems on the Global Positioning System (GPS) and certain types of radio navigation. Waypoints located on the surface of the earth are usually defined in two dimensions, longitude, and latitude, while those used in the atmosphere of the earth or in space are defined in at least three dimensions or four if time is one of the coordinates for some points outside Earth. The use of this formula is quite accurate for most calculations, also ignoring the height of the hill and the depth of the valley on the surface of the earth [5]. The search for haversine is written with the following equation.

$$
\begin{aligned}
& x=\left(\operatorname{lon}_{2}-\operatorname{lon}_{1}\right) * \cos \left(\frac{\text { lat }_{1}+\text { lat }_{2}}{2}\right) ; \\
& y=\left(\operatorname{lat}_{2}-\operatorname{lat}_{1}\right) ; \\
& d=\operatorname{sqrt}(x * x+y * y) * R
\end{aligned}
$$

With:

X: Longitude,

Y: Latitude,

$\mathrm{d}$ : Distance

$\mathrm{R}=$ Earth Radius $=6371 \mathrm{~km},(1$ degree $=0.0174532925$ radian $)$.

Angles on formulas use radians to use trigonometric functions. The haversine formula is used in this study to calculate the range of the radius of search for Islamic boarding schools whose position is closest to the user. This formula is also used to substitute the calculation of the distance between the position of the Islamic boarding school and the user's position.

This algorithm will be used to calculate the distance between two GPS coordinate points. In this case the coordinate point of the user's position with the position of the coordinated destination, so that this algorithm becomes the main key to determine the distance between the user's position and the Islamic boarding school based on the radius. Figure2 ball triangle with the following Haversine Formula law. 


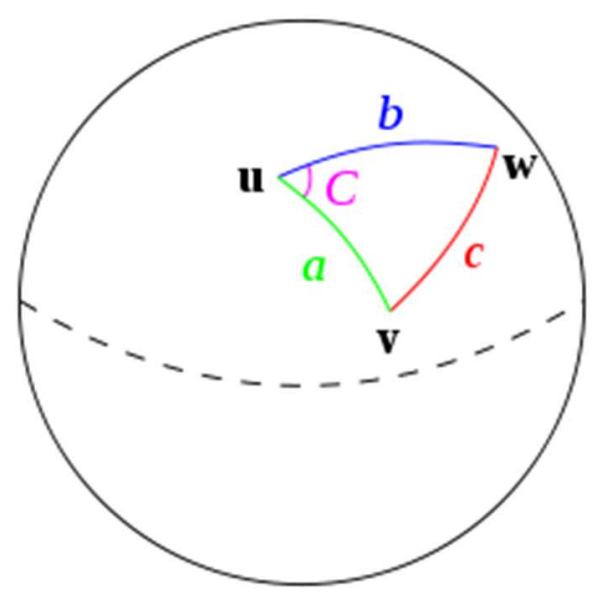

Figure 2. The ball triangle with the Haversine Formula law

If the lengths of the three sides are $a(u$ to $v$ ), $b$ (from $u$ to $w$ ), and $c$ (from $v$ to $w$ ), and the opposite angle $\mathrm{c}$ is $\mathrm{C}$, then the law of haversine formula is as follows. Haversine $(\mathrm{c})=$ haversine $(a-b)+\sin (a) \sin (b)$ haversine (c).

In search of distance, the Haversine Formula method can be used in the calculation between the current position to the location using latitude and longitude. Following is an example of calculating the distance using Haversine Formula, point A is the Sunan Gunung Djati Bandung Islamic University, A.H. Nasution Cibiru (-6.9316435, 107.7150027) and point B is the Jakarta National Monument $(-6.1753871,106.8249641)$. if it is displayed on Google Maps it will be as shown in Figure3 as follows.

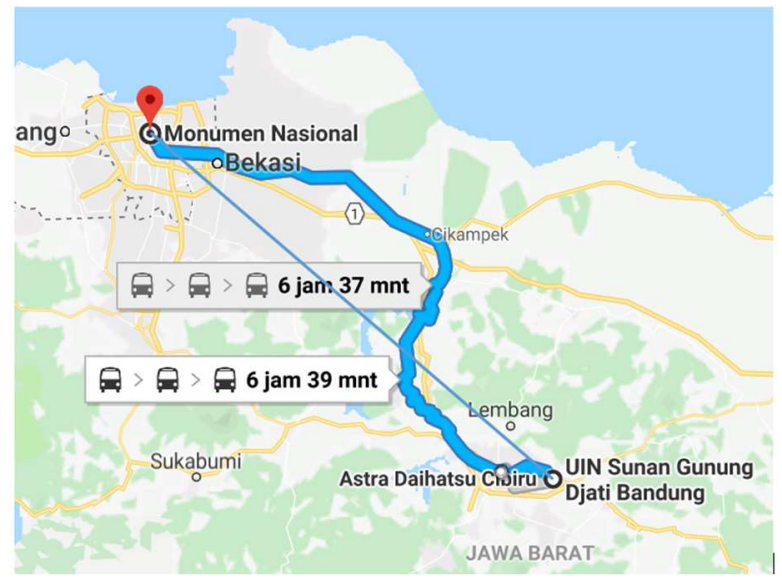

Figure 3. Distance between 2 locations on Google Maps 
From the map, there are 2 points between UIN Bandung and the National Monument Monument, so:

$$
\begin{array}{llll}
\text { Lat } 1 & :-6.9316435 & \text { long } 1 & : 107.7150027 \\
\text { Lat } 2 & :-6.1753871 & \text { long } 2 & : 106.8249641
\end{array}
$$

First, multiply latitude and longitude with a radius.

$$
\begin{array}{ll}
\text { Lat } 1 & =-6.9316435 * 0.0174532925 \text { radian } \\
& =-0.120980001 \text { radian } \\
\text { Lon } 1 & =107.7150027 * 0.0174532925 \text { radian } \\
& =1.879981449 \text { radian } \\
\text { Lat } 2 & =-6.1753871 * 0.0174532925 \text { radian } \\
\text { Lon 2 } & =-0.107780837 \text { radian } \\
& =106.8249641 * 0.0174532925 \text { radian } \\
& =1.864447345 \text { radian }
\end{array}
$$

After obtaining from the multiplication, then it is entered into the formula haversine formula as follows:

$$
\begin{aligned}
x= & \left(\operatorname{lon}_{2}-\operatorname{lon}_{1}\right) * \cos \left(\frac{\text { lat }_{1}+\text { lat }_{2}}{2}\right) \\
= & (1.864447345-1.879981449) * \cos \left(\left(-0.120980001+\frac{-0.107780837}{2}\right)\right. \\
= & (0.015534104) * \cos \frac{-0.013199164}{2} \\
& =0.015534104 * \cos (-0.006599582)=0.015533765=>0.0153377 \\
y & =\left(l_{2}-\text { lat }_{1}\right) \\
& =(-0.107780837-(-0.120980001) \\
& =0.01317631 \\
d & =\operatorname{sqrt}(x * x+y * y) * R \\
& =\operatorname{sqrt}\left(0.0153377^{2}+0.01317631^{2}\right) * 6371 \\
& =\operatorname{sqrt}(0.004147898) * 6371 \\
& =\sqrt{0.004147898} * 6371 \\
& =6.020366388 * 6371 \\
& =129.7542579 \quad=>129.7 \mathrm{~km}
\end{aligned}
$$

Then the distance obtained between the location of the UIN Bandung and the Jakarta National Monument using the Haversine Formula algorithm is $129.7 \mathrm{~km}$.

\section{Euclidian Distance Algorithm}

Euclidean distance is a method for searching distances between 2 coordinate points, which in this method is a distance calculation using the latitude and longitude [9]. The following is an example of calculating the distance using Euclidian Distance Algorithm, point A is the Sunan Gunung Djati State Islamic University Bandung A.H. Nasution Cibiru road (-6.9316435, 107.7150027) and point B is the Jakarta National Monument (-6.8917817,107.7358739).

Then obtained: 
Lat $1=-6.9316435 \quad$ long $1=107.7150027$

Lat $2=-6.1753871 \quad$ long $2=106.8249641$

The Euclidean distance formula is as follows:

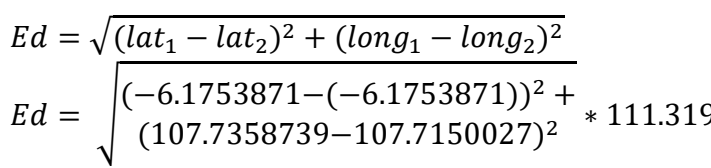

First, calculate the latitude and longitude parts to be as follows.

$E d=\sqrt{(0.7562564)^{2}+(0.8900386)^{2}} * 111.319$

Calculate by lifting each one.

$E d=\sqrt{1.364092452} * 111.319$

$E d=1.167943685 * 111.319$

$=130,014$

Then the results obtained from the distance between UIN Bandung to Jakarta national monument are $=130 \mathrm{~km}$.

\section{Comparison of the Haversine Formula and Euclidean Distance Algorithms}

The search system for the location of the nearest boarding school can calculate the distance between 2 coordinate points using the haversine formula and Euclidean Distance algorithm. From the calculation results, the distance from UIN Bandung to the Jakarta National Monument is obtained.

The results of the google map distance between UIN Bandung to the Jakarta National Monument is $129 \mathrm{~km}$, while the results obtained using the haversine formula algorithm are 129.7 $\mathrm{km}$ while using the Euclidean Distance algorithm is $130 \mathrm{~km}$, therefore the calculation of the Euclidean Distance and haversine formula algorithm is more accurate than with google maps.

The difference from google maps with the algorithm used is quite far, which is $3 \mathrm{~km}$, therefore the haversine and Euclidean distance algorithms are quite accurate in calculating distances.

\section{Implementation}

\subsection{Home Page}

The Android home page is the starting page on Android. On this page, there are 4 menu choices including, maps menu, category menu, news menu, and menu about. Can be seen in Figure 4. 


\subsection{Maps Page}

On this page, the community can see Islamic boarding schools using 2D maps, in which there will be all Islamic boarding schools in West Java. Can be seen in Figure5.

\subsection{Category Page}

On the category page, the community can choose a cottage by category. These categories include Nadhlatul Ulama, Persatuan Islam, and Muhammadiyah. Display of categories can be seen in Figure6.

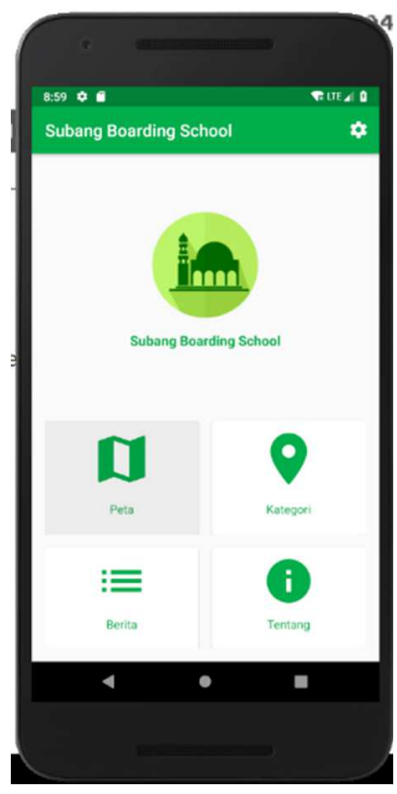

Figure 4. Homepage display

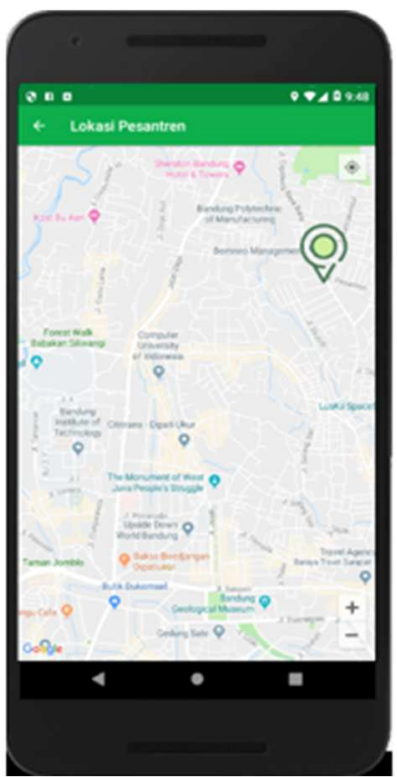

Figure 5. Maps display

\subsection{List Pondok Pesantren}

This page is a page after selecting a category, the list of boarding schools will appear. On this page, all Islamic boarding schools will appear at a distance. Can be seen in Figure 7. 


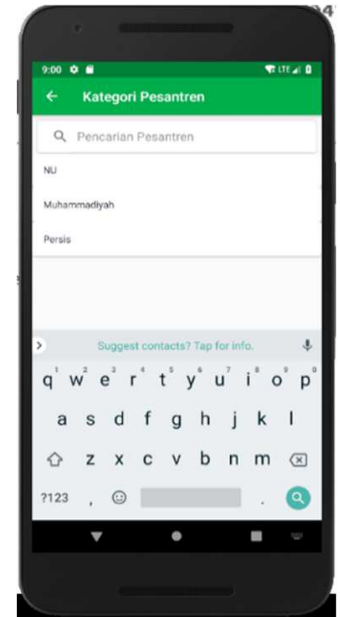

Figure 6. Category Page

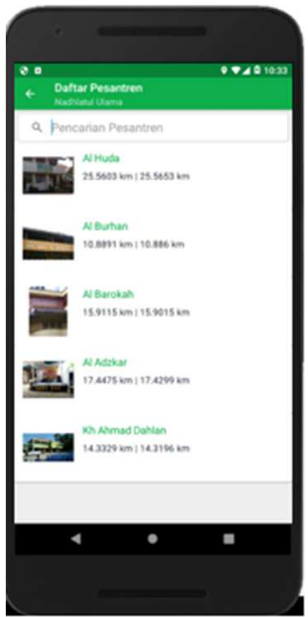

Figure 7. Boarding School List

\subsection{Detail Page}

On the detail page contains detailed information from the Islamic Boarding Schools that were previously selected. Data in the form of address, contact, and distance from the starting point.

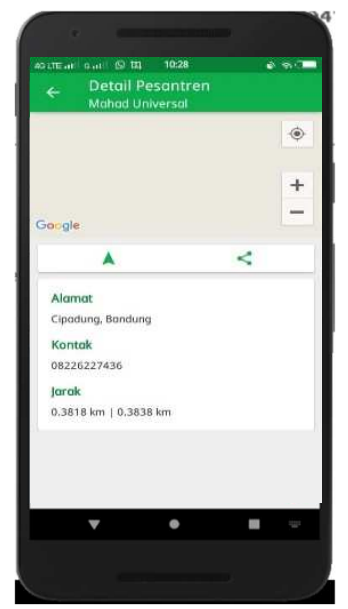

Figure 8. Boarding School details page 


\section{Result and Discussion}

The test results from the Haversine Formula and Euclidean Distance algorithms are then compared with the distance from Google map, so the test data is obtained as follows. In this test, the starting point came from the same location, namely UIN Sunan Gunung Djati Bandung.

Table 1. Comparison of Algorithm

\begin{tabular}{lllll}
\hline No & End Point (Destinations) & Google Maps & Haversine Formula & Euclidean Distance \\
\hline 1 & Al Falah & $14.7 \mathrm{~km}$ & $14.7553 \mathrm{~km}$ & $14.7616 \mathrm{~km}$ \\
2 & Al Hidayah & $15.06 \mathrm{~km}$ & $15.1202 \mathrm{~km}$ & $15.1271 \mathrm{~km}$ \\
3 & As Syfa & $13.1 \mathrm{~km}$ & $13.2033 \mathrm{~km}$ & $13.2072 \mathrm{~km}$ \\
4 & Al Mukhlis & $24.7 \mathrm{~km}$ & $24.1492 \mathrm{~km}$ & $24.1854 \mathrm{~km}$ \\
5 & Miftahul Jaza & $30.4 \mathrm{~km}$ & $30.1154 \mathrm{~km}$ & $30.1339 \mathrm{~km}$ \\
6 & Persis No 84 Ciganitri & $10 \mathrm{~km}$ & $10.0644 \mathrm{~km}$ & $10.0771 \mathrm{~km}$ \\
7 & Al Mukhlisin & $11.1 \mathrm{~km}$ & $11.1709 \mathrm{~km}$ & $11.1819 \mathrm{~km}$ \\
8 & Yayasan Salafiyah A & $15.22 \mathrm{~km}$ & $15.2919 \mathrm{~km}$ & $15.2979 \mathrm{~km}$ \\
9 & Al Misbah & $7.6 \mathrm{~km}$ & $7.6708 \mathrm{~km}$ & $7.71 \mathrm{~km}$ \\
10 & Darul Hikmah & $13.58 \mathrm{~km}$ & $13.6552 \mathrm{~km}$ & $13.1367 \mathrm{~km}$ \\
11 & Persis 31 Banjaran & $20.15 \mathrm{~km}$ & $20.2268 \mathrm{~km}$ & $10.2704 \mathrm{~km}$ \\
12 & Darul Ulum & $12 \mathrm{~km}$ & $12.0434 \mathrm{~km}$ & $12.0294 \mathrm{~km}$ \\
13 & Mathla'ul Huda & $13.4 \mathrm{~km}$ & $13.4645 \mathrm{~km}$ & $13.5109 \mathrm{~km}$ \\
14 & Al Ihsan & $14.31 \mathrm{~km}$ & $14.3851 \mathrm{~km}$ & $14.4119 \mathrm{~km}$ \\
15 & Al Basyariyah 3 & $19.78 \mathrm{~km}$ & $19.8574 \mathrm{~km}$ & $19.864 \mathrm{~km}$ \\
16 & Al Huda & $25.5 \mathrm{~km}$ & $25.5603 \mathrm{~km}$ & $25.5653 \mathrm{~km}$ \\
17 & Al Burhan & $10.8 \mathrm{~km}$ & $10.8891 \mathrm{~km}$ & $10.886 \mathrm{~km}$ \\
18 & Al Barokah & $15.2 \mathrm{~km}$ & $15.9115 \mathrm{~km}$ & $15.9015 \mathrm{~km}$ \\
19 & Al Adzkar & $17.37 \mathrm{~km}$ & $17.4475 \mathrm{~km}$ & $17.4299 \mathrm{~km}$ \\
20 & Ahmad Dahlan & $14.26 \mathrm{~km}$ & $14.3329 \mathrm{~km}$ & $14.3196 \mathrm{~km}$ \\
\hline
\end{tabular}

The results of testing of the haversine formula and Euclidean distance on the search for the location of the nearest Islamic boarding school were then tested for the accuracy level as follows.

$$
\begin{aligned}
\text { Accuracy }= & \frac{\text { Amount of Correct Data }}{\text { Amount of overall data }} \times 100 \% \\
& =\frac{18}{20} \times 100 \%=85 \%
\end{aligned}
$$

So the accuracy of the haversine algorithm and the Euclidean distance is $85 \%$.

Accuracy is a formula for calculating the accuracy made after testing with 20 test rules contained in the system and resulting in 3 failures, then a total accuracy of $85 \%$ is obtained. This number is the accuracy given based on the performance of the haversine formula algorithm and Euclidean distance to the system. 


\section{Conclusion}

The application of the haversine formula and Euclidean distance algorithms on the nearest location search application was successfully built and can be used to search for Islamic boarding schools in West Java so that people can choose and search for the closest Islamic boarding schools in the community using Android. The application is made capable of displaying all Islamic boarding schools in West Java equipped with information and distance to the location of Islamic boarding schools. The haversine formula and Euclidean distance algorithms can provide distance accuracy to the location. The level of accuracy of Euclidean distance is higher than the haversine formula by showing the average distance difference of $0.07 \mathrm{~km}$ from 20 trials.

\section{References}

[1] Eu. Black, "Inside Indonesia's largest Islamic boarding school," 2017. [Online]. Available: https://southeastasiaglobe.com/in-pictures-inside-indonesias-largest-islamic-boarding-school/.

[Accessed: 24-Jun-2019].

[2] Muhyiddin and Agus Yulianto, "Pertumbuhan Pesantren di Indonesia Dinilai Menakjubkan | Republika Online." [Online]. Available: https://www.republika.co.id/berita/dunia-islam/islamnusantara/17/11/30/p088lk396-pertumbuhan-pesantren-di-indonesia-dinilai-menakjubkan.

[Accessed: 24-Jun-2019].

[3] KEMENAG, "Pangkalan Data Pondok Pesantren," 2019. [Online]. Available: http://pbsb.ditpdpontren.kemenag.go.id/pdpp/search. [Accessed: 24-Jun-2019].

[4] "10 Tips Memilih Pondok Pesantren yang Tepat Untuk Anak." [Online]. Available: https://www.renesia.com/10-tips-memilih-pondok-pesantren/. [Accessed: 25-Jun-2019].

[5] C. D. Kurniawan, "Sistem Pencarian Wisata Indonesia Terdekat dengan Haversine Formula dan 360 Degree," Bimasakti, pp. 1-8, 2014.

[6] Heri Setiawan, "Implementasi Haversine Formula pada Lokasi Pariwisata Berbasis Smartphone," J. Fahma, vol. 14, no. 2, Mar. 2016.

[7] I. Irwan and D. Atmajaya, "Sistem Informasi Pencarian Lokasi Perguruan Tinggi di Makassar," Ilk. J. Ilm., vol. 10, no. 2, p. 232, Aug. 2018.

[8] F. Farid and Y. Yunus, "Analisa Algoritma Haversine Formula untuk Pencarian Lokasi Terdekat Rumah Sakit dan Puskesmas Provinsi Gorontalo," Ilk. J. Ilm., vol. 9, no. 3, p. 353, Dec. 2018.

[9] F. Falanda, R. Gustriansyah, and Hartini, "Disekitar Pengguna Dikota Palembang Dengan," J. Ilm. Inform. Glob., vol. 7, no. 1, pp. 17-24, 2016. 